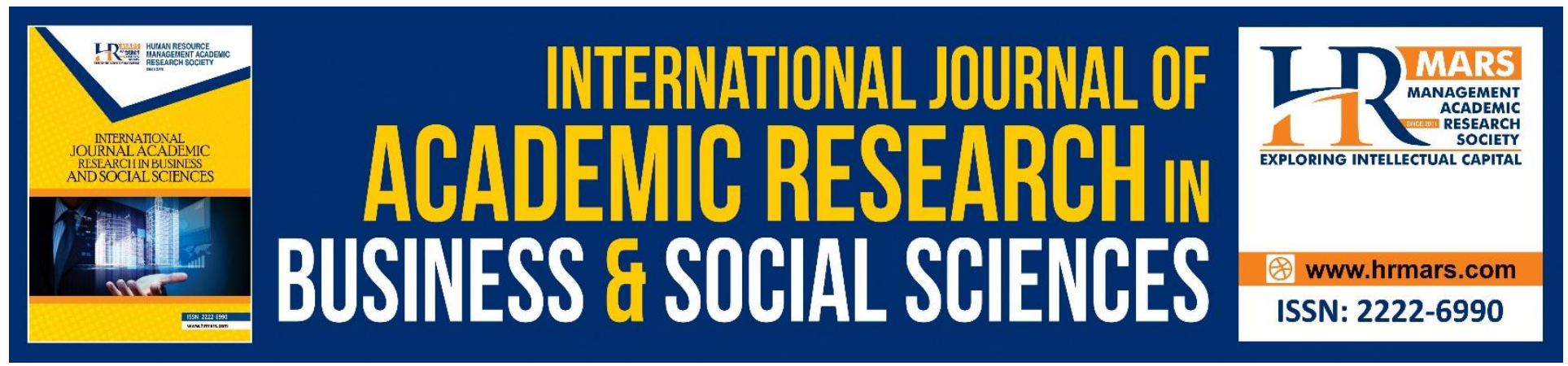

\title{
The Impacts of Perceived Service Quality on Attendees' Satisfaction
}

Nurakmal Ramli, Wan Soraya Wan Abdul Ghani, Hairunnisa Ma'mor and
Norhidayah Mohd Rashid

To Link this Article: http://dx.doi.org/10.6007/IJARBSS/v8-i11/5569

DOI: $10.6007 /$ IJARBSS/v8-i11/5569

Received: 05 Nov 2018, Revised: 28 Nov 2018, Accepted: 05 Dec 2018

Published Online: 09 Dec 2018

In-Text Citation: (Ramli, Ghani, Ma'mor, \& Rashid, 2018)

To Cite this Article: Ramli, N., Ghani, W. S. W. A., Ma'mor, H., \& Rashid, N. M. (2018). The Impacts of Perceived Service Quality on Attendees' Satisfaction. International Journal of Academic Research in Business and Social Sciences, 8(11), 2066-2074.

Copyright: (C) 2018 The Author(s)

Published by Human Resource Management Academic Research Society (www.hrmars.com)

This article is published under the Creative Commons Attribution (CC BY 4.0) license. Anyone may reproduce, distribute, translate and create derivative works of this article (for both commercial and non-commercial purposes), subject to full attribution to the original publication and authors. The full terms of this license may be seen

at: http://creativecommons.org/licences/by/4.0/legalcode

Vol. 8, No. 11, 2018, Pg. 2066 - 2074

http://hrmars.com/index.php/pages/detail/IJARBSS

JOURNAL HOMEPAGE

Full Terms \& Conditions of access and use can be found at http://hrmars.com/index.php/pages/detail/publication-ethics 


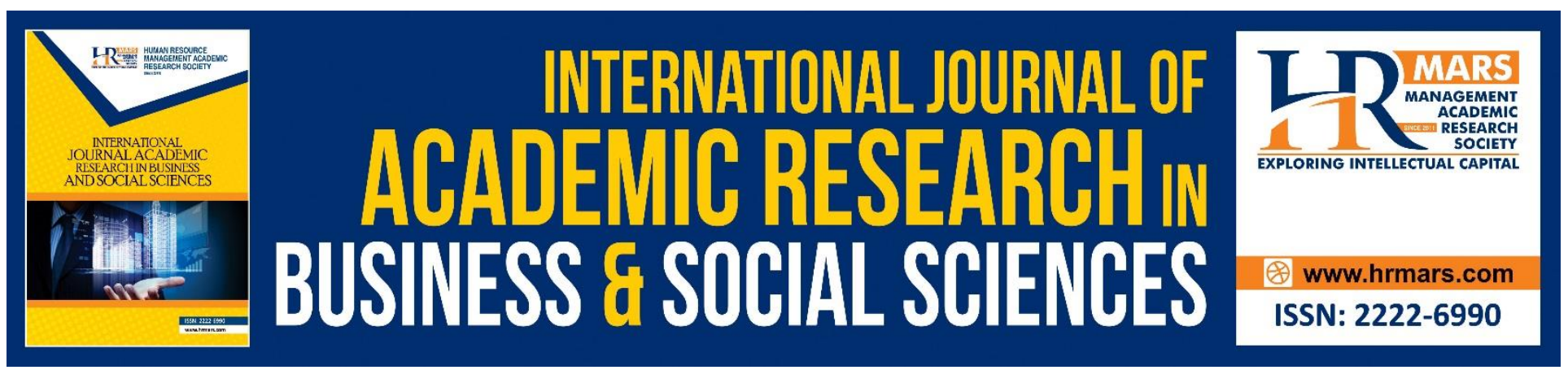

\title{
The Impacts of Perceived Service Quality on Attendees' Satisfaction
}

\section{Nurakmal Ramli, Wan Soraya Wan Abdul Ghani, Hairunnisa Ma'mor and Norhidayah Mohd Rashid}

Universiti Teknologi MARA Selangor, Department of International Business and Management

Studies, Faculty of Business and Management, 42300, Bandar Puncak Alam, Malaysia

\begin{abstract}
Background: customer's satisfaction for the success of an exhibition. It is crucial for exhibitors to recognize the attendee's perspectives towards the service quality to improve the deliverance of an exhibition performance. Objective: The aim of this study is to examine the relationship between attendees' perceptions and the satisfaction in attending exhibitions in Malaysia. Results: The results show that there is a significant relationship between service quality and attendee's satisfaction. Conclusion: The results indicate that two of the five service quality dimensions have positive impact on attendees' satisfaction. This finding therefore will help event organizers in improving the service quality and performance of an exhibition.
\end{abstract}

Keywords: Exhibition, Attendees' perception, Event Management

\section{Introduction}

The meeting, incentive, convention and exhibition (MICE) industry has been identified as potential sector for the growth of Malaysia's economy. Under Malaysia's Economic Transformation Programme (ETP), the business event is projected to generate RM3.9 billion (USD 6) increment GNI and provide 16,700 jobs in various fields (PEMANDU, 2010). Recognizing the importance of the MICE industry in Malaysia especially exhibition industry; it is essential to know the requirements for the industry to remain competitive and successful. Attendees' satisfaction is one of the important aspects which affected the success of an exhibition. In today's competitive environment, improving service quality has become one of the conditions for success and a crucial aspect of business and industry development (Shemwell, Yavas and Bilgin, 1998). Exhibition allows exhibitors to reach target market with a diverse interest in the products exhibited (Lee, Lee and Joo, 2015). Appropriate planning and execution of exhibition will ensure the exhibitors' message will be effectively delivered to potential customers and improve business image in relatively short time (Rainbolt, Benfield and Loomis, 2012). Consequently, for the continued growth of exhibition industry in Malaysia, it is crucial for event organizer to identify the expectations and perception of attendees on the service quality. Therefore, 
this study is conducted to identify the perception of service quality of attendees at Café Malaysia 2017, and to identify the relationship of the service quality of an exhibition and attendees satisfaction to ensure the exhibition industry to remain competitive and successful.

Service quality as in the SERVQUAL model developed by Parasuraman, Zeithaml, and Berry (1988) can be defined as the overall judgment or attitude toward the superiority of service relative to competing offerings. This SERVQUAL model is widely used to measure perceived service quality. However, SERVQUAL model discrepancy measure has been broadly criticized as it may not be sufficient for measuring service quality across different industries and circumstances (Chen and Mo, 2012; Jung, 2005; Lee et al., 2015). There are numerous researches that investigate the relationship between service quality and customer satisfaction (Ayob and Said, 2010; Sureshchandar, Rajendran and Anantharaman, 2002; Zhang, Lee, Judge and Johnson, 2014). Gronross (1984) defined service quality as the difference between the expected service and perceived service from the customer perspectives. Perceived service quality depicts overall judgment of service that could arise at many aspects of the organization including main service, the interaction with service providers, and the environments etc. (Sureshchandar et al., 2002). In addition, Brady and Cronin (2001) discovered that perception of service quality is determined by three aspects; outcome quality, interaction quality and physical environment quality. Outcome quality is refers to the end product that customer received, interaction quality measures the interaction during the delivery of services while physical environment quality refers to the surroundings and environments where the service is delivered.

Customer satisfaction in service marketing relates with future behavioral intention to repeat purchase and positive word of mouth (Choi and Chu, 2001; Oliver, 1980). Customer satisfaction is described as an evaluation of pleasant consumption-related fulfillment that a product or service feature, or the product or service offered (Oliver, 1997). High quality services that can satisfy customer requirements are the key to achieve sustainable advantage (Shemwell et al., 1998). As the satisfactions of visitors become the key for the success of exhibitions, the service quality is determined through the perceptions of the attendees (Chen and Mo, 2012). However there is a lack of studies that identify the attendees' perspective on service quality and how it affects the satisfaction in exhibition industry. Several studies found that poor overall ratings on exhibition and attendees' dissatisfaction stem from interaction with booth personnel, booth design, promotion and booth staffing (Chonko, Tanner and Mckee, 1994) and unknowledgeable and incompetent booth personnel (Gopalakrishna and Williams, 1992).

Study by Jung (2005) identified six dimensions of service quality from the perception of the attendees: booth management, registration, content of activities, booth and exhibition attractiveness, booth layout and function and access. The content of activities was found as the important dimension of service quality that determines the attendees' satisfaction. The attendees were interested with the numbers of exhibitors, the products and services offered, sufficient information materials, and exhibition related events including conference, and seminars. Other study by Blythe (1999) found that most attendees are concerned in new products and collecting information and emphasize more on information supplying role rather than intensive selling activities. Exhibition allowed attendees to scrutinize products, to check how products work, search something new and innovation, enjoy entertainment at the exhibition and to observe the market (Rittichainuwat and Mair, 2012). Likewise, Kozak and Kayr (2009) found that the most important 
motivation for exhibition attendance are learning about the product displayed, gathering information about new products and seeing particular new products and companies. Attending exhibition creates an opportunity for attendees to collect information from various vendors in a onestop shopping occasion (Dwyer and Tanner, 2002). Attendees' decisions to attend an exhibition are depending on their perceptions of essential exhibitions aspects and exhibition information (Berne and Garcia-Uceda, 2008). Therefore, it is essential for exhibitors to provide sufficient information concerning their products and services in order to satisfy customers need.

Nevertheless, booth content (signage, product display, skill set of booth personnel) also play an important role to reflect attendee's objectives and characteristics in order to satisfy the attendees requirements (Bello and Lohtia, 1993). This is because most exhibition attendees are motivated to view particular products and more satisfied with effective booth design with proper signage and convenience booth layout (Blythe, 1999; Whitfield and Webber, 2011). Design of the exhibition booths can be viewed from spatial or ergonomic layouts and booth contents that can attract more attendees (Whitfield and Webber, 2011). Furthermore, visitors are more encouraged to interact with exhibitors in sufficient interaction spaces (Wan and Siu, 2012). Lin and Lin (2013) suggested that booth design and layout are intensely related to attendees' satisfaction. Additionally, the quality and the number of exhibition booths are essential as the floor space is the fundamental for exhibitor and attendees interaction (Bitner, 1992; Whitfield and Webber, 2011). Meanwhile, Smith, Hama and Smith (2003) point out that understanding of international attendees' perceptions of trade shows and exhibitions will assist in show selection, at-show message development, booth design and staffing decision.

Attendees are the root of convention or exhibition (Jung, 2005). They play important roles in the success of an event. Achieving customer's satisfaction definitely become the aims of event organizers. Moreover, knowledge of the drivers of successful attendance and repeat attendance will improve the customer relationship management tool in trades shows and exhibition's business environment where sales opportunities have gradually become difficult (Smith et al. 2003).

\section{Methodology}

A survey method was used in this study. A total set of 300 questionnaires were distributed to the attendees of Café Malaysia Exhibition 2017 at MATRADE Exhibition and Convention Centre. Café Malaysia series, first launched in 2015, is the largest gathering of the tea and coffee industries in Malaysia and one of the largest in Southeast Asia. This exhibition hosted 138 exhibitors from 18 countries. Out of the 300 questionnaires, 232 were valid and used for analysis, representing a response rate of $77 \%$. In determining the sample, the convenience sampling has been used. The questionnaire items were adapted from Chen and Mo (2012) and Jung (2005). All items for service quality and attendees' satisfaction were assessed with 5-point Likert scale ranging from "strongly disagree (1) to "strongly agree (5). Descriptive analysis, reliability analysis, correlation analysis and multiple regression analysis were conducted to analyze the data. Reliability analysis was performed to measure the consistency of the item by using Cronbach's Alpha. According to Malholtra (2004), a Cronbach's alpha value of 0.60 and above is considered acceptable. The Cronbach's alpha value for attendee's satisfaction items is 0.792 indicating that the items used is acceptable. Meanwhile, the Cronbach's alpha for all five independent variables show the values of 0.690 (content activities), 
INTERNATIONAL JOURNAL OF ACADEMIC RESEARCH IN BUSINESS AND SOCIAL SCIENCES

Vol. 8, No. 11, Nov, 2018, E-ISSN: 2222-6990 @ 2018 HRMARS

0.683 (exhibition attractiveness), 0.784 (registration), 0.697 (booth management) and 0.526 (booth layout). The findings indicate that all the variables obtained the acceptable value with the exception of booth layout's variable. Correlation analysis and multiple regression analysis were performed to examine the relationship between perceived service quality and attendees' satisfaction.

\section{Results}

\section{Profile of Respondents}

Out of the 232 of respondents, 97(41.8\%) were males, 135 (58.2\%) were females. Most of the respondents aged between 21-30 years old representing $82(35.3 \%)$ of respondents. With regards to education level, 70 (30.2\%) have SPM, 66 (28.4\%) have diploma, 69 (29.7\%) have bachelor degree, 13(5.6\%) obtained master level of education and 14 (6\%) others. Pertaining to occupation level, 120 (51.7\%) were employed, 19 (8.2\%) were unemployed and 83 (35.8\%) were students. Examining the frequency of attending exhibition, 126 (54.3\%) have visited between 1-3 times, 87 (37.5\%) have visited between 4-6 times, 17 (7.3) have visited between 7-10 times and 2 (9\%) have visited more than 10 times.

Table 1: Correlation analysis and Cronbach's alpha results

\begin{tabular}{|l|c|c|c|c|c|c|c|c|}
\hline & $\mathbf{M}$ & SD & $\mathbf{1}$ & $\mathbf{2}$ & $\mathbf{3}$ & $\mathbf{4}$ & $\mathbf{5}$ & $\mathbf{6}$ \\
\hline $\begin{array}{l}\text { Content } \\
\text { Activities }\end{array}$ & 3.81 & .533 & $(0.690)$ & & & & & \\
\hline $\begin{array}{l}\text { Exhibition } \\
\text { Attractiveness }\end{array}$ & 3.71 & .559 & $.546^{* *}$ & $(0.683)$ & & & & \\
\hline Registration & 3.73 & .653 & $.347^{* *}$ & $.326^{* *}$ & $(0.784)$ & & & \\
\hline $\begin{array}{l}\text { Booth } \\
\text { Management }\end{array}$ & 3.72 & .611 & $.445^{* *}$ & $.542^{* *}$ & $.359^{* *}$ & $(0.697)$ & & \\
\hline Booth Layout & 3.61 & .556 & $.421^{* *}$ & $.332^{* *}$ & $.491^{* *}$ & $3.72^{* *}$ & $(0.526)$ & \\
\hline $\begin{array}{l}\text { Attendees } \\
\text { Satisfaction }\end{array}$ & 3.83 & .636 & $.343^{* *}$ & $.321^{* *}$ & $.525^{* *}$ & $.358^{* *}$ & $.431^{* *}$ & $(0.792)$ \\
\hline
\end{tabular}

Pearson correlation has been conducted to confirm the linear relationship and result found that content activities $(r=0.343 p<0.01)$, exhibition attractiveness $(r=0.321 p<0.01)$, registration $(r=0.525$ $p<0.01)$, booth management $(r=0.358 p<0.01)$, and booth layout $(r=0.431 p<0.01)$ have positive and moderately significant with attendees' satisfaction towards Café Malaysia Exhibition 2017. 
INTERNATIONAL JOURNAL OF ACADEMIC RESEARCH IN BUSINESS AND SOCIAL SCIENCES

Vol. 8, No. 11, Nov, 2018, E-ISSN: 2222-6990 @ 2018 HRMARS

Table 2: Multiple Regression Analysis results

\begin{tabular}{|l|c|c|}
\hline Variables & $\begin{array}{c}\text { Beta } \\
\text { Value }\end{array}$ & $\begin{array}{c}\text { Sig } \\
(\mathrm{p}<0.05)\end{array}$ \\
\hline $\begin{array}{l}\text { Content } \\
\text { Activities }\end{array}$ & 0.072 & 0.295 \\
\hline $\begin{array}{l}\text { Exhibition } \\
\text { Attractiveness }\end{array}$ & 0.051 & 0.473 \\
\hline Registration & 0.364 & 0.000 \\
\hline $\begin{array}{l}\text { Booth } \\
\text { Management }\end{array}$ & 0.107 & 0.115 \\
\hline Booth Layout & 0.165 & 0.013 \\
\hline$R$ & \multicolumn{2}{|c|}{0.584} \\
\hline R & \multicolumn{2}{|c|}{0.341} \\
\hline Adjusted $R^{2}$ & 23.420 \\
\hline F & \multicolumn{2}{|c|}{} \\
\hline
\end{tabular}

Since there are positive correlations between all the dimensions, a multiple regression analysis was conducted to further examine see whether there is influence of service quality on attendees' satisfaction. Based on Table 2, the adjusted $R^{2}$ of this study is 0.327 with the $R^{2}=.341$ interpret that the linear regression explains 34.1 percent of the variances in the attendees' satisfaction explained by content activities, exhibition attractiveness, registration, booth management and booth layout. Results shown that only two dimensions of service quality namely; registration $(\beta=.000, p<0.05)$ and booth layout $(\beta=.013, p<0.05)$ are statistically significant influences on attendees' satisfaction. On the other hand, content activities $(\beta=.295, p<0.05)$, exhibition attractiveness $(\beta=.473, p<0.05)$ and booth management $(\beta=.115, p<0.05)$ show no significant values which indicate that the dimensions do not influence the attendees' satisfaction.

\section{Discussion}

The correlations analysis revealed that all the perceive service quality dimensions have positive and significant relationship with attendees' satisfaction. These results imply that increase in each quality service dimensions is likely to lead to the increase in attendees' satisfaction. This finding is consistent with the prevailing position in the previous studies that service quality is a major predictor of customer satisfaction (Ayob and Said, 2010; Sureshchandar et al., 2002; Zhang et al., 2014). Multiple regression analysis indicates that only registration and booth layout have a significant impact on attendees' satisfaction. These findings are contradict with studies conducted by Chen and Mo (2012) and Jung (2005) that indicated content activities was found as the most important dimensions of service quality of an exhibition. The difference research result may be due to the fact that the study was conducted under different service contexts. Attendees at Café Malaysia 2017 are most satisfied with the efficient registration that optimizes the use of technology in the registration process. On the other hand, Jung (2005) found that booth layout was the second most important dimension of service quality thus supported the findings of this study. The importance of booth layout in determining the 
INTERNATIONAL JOURNAL OF ACADEMIC RESEARCH IN BUSINESS AND SOCIAL SCIENCES

Vol. 8, No. 11, Nov, 2018, E-ISSN: 2222-6990 @ 2018 HRMARS

satisfaction of attendees may vary depending on the design of the booths in term of spatial and ergonomic layouts that can attract more attendees (Whitfield and Webber, 2011).

\section{Conclusion}

The study aim was to examine the impact of perceived serviced quality towards attendees' satisfaction at Café Malaysia 2017 Exhibition. The service qualities of registration and booth layout are found to be the most priority for the atteendee's at Café Malaysia 2017. The implications of this study for exhibitor and exhibition organizer are mostly concerned with designing the layout and space of booths that can enhance the attendees satisfaction. Besides, the use of the efficient technogy in the exhibition especially for the registration process can be considered as a potential aspect to attract the attendees and enhance their satisfaction.

However, the study includes limitations that need to be taken into considerations. Each of the dimensions have different attribution and quality that satisfies the attendees. The relative importance of specific dimensions of service quality may vary across different exhibition and even across different industries. Nonetheless, the basic finding of this research should be able to add to the study about the relationships of service quality and customer satisfaction. Moreover, this study should support event organizer in continuing providing and improving service quality in exibition industry.

\section{Acknowledgements}

This study was financially supported by LESTARI Grant from Institute of Research Management and Innovation (IRMI), Universiti Teknologi MARA (UiTM), Malaysia.

\section{Corresponding Author}

Nurakmal Ramli, Universiti Teknologi MARA Selangor, Malaysia, Department of International Business and Management Studies, Faculty of Business and Management, 42300, Bandar Puncak Alam, Malaysia.

Email: nurakm2956@puncakalam.uitm.edu.my

\section{References}

Ayob, N. \& Said, A. (2010). Service quality and customer satisfaction within festival and special event. Proceeding of the Knowledge Management International Conference (Kmice2010), 5, pp 3237.

Bello, D. \& Lohtia, R. (1993). Improving trade show effectiveness by analyzing attendees. Industrial Marketing Management, 22(4), 311-318.

Bitner, M. J. (1992). Servicescapes: The impact of physical surroundings on customers and employees. Journal of Marketing, 56(1), 57-71.

Blythe, J. (1999). Visitor and exhibitor expectations and outcomes at trade exhibitions. Marketing Intelligence and Planning, 17(2), 100-108.

Berne, C. \& Garcia-Uceda, M.E. (2008). Criteria involved in evaluation of tradeshows to visit. Industrial Marketing Management, 37, 565-579. 
INTERNATIONAL JOURNAL OF ACADEMIC RESEARCH IN BUSINESS AND SOCIAL SCIENCES

Vol. 8, No. 11, Nov, 2018, E-ISSN: 2222-6990 @ 2018 HRMARS

Brady, M. \& Cronin, J. (2001). Some new thoughts on conceptualizing perceived service quality: a hierarchical approach. Journal of Marketing, 65(3), 34-49.

Chen, Y.F. \& Mo, H.E. (2012). Attendees' perspectives on the service quality of an exhibition organizer: A case study of a tourism exhibition. Tourism Management Perspectives, 1, 28-

33.

Choi, T.Y. \& Chu, R (2001). Determinants of hotel guests' satisfaction and repeat patronage in the Hong Kong hotel industry. International Journal of Hospitality Management, 20(1), 277-297. Chonko, L.B., Tanner, J.F., \& McKee, J. (1994). Behind the booths. Marketing Management, 31(1), 40-43.

Dwyer, F. R., \& Tanner, J. F. (2002). Business marketing: Connecting strategy, relationships, and learning. Boston: Irwin/McGraw Hill.

Gopalakrishna, S., \& William, J.D. (1992). Planning and performance of industrial trade shows: An explatory study. International Journal of Research in Marketing, 9, 207- 224.

Gronross, C. (1984). A service quality model and its marketing implications. European Journal of Marketing, 18(4), 36-44.

Jung, M. (2005). Determinants of exhibition service quality as perceived by attendee. Journal of Convention \& Event Tourism, 7, 85-98.

Kozak, N. \& Kayr, C.H. (2009). Visitors' objectives for trade show attendance: a case study on the East Mediterranean international tourism and travel exhibition (EMITT). Event Management, 12, 1-17.

Lee, M.J., Lee, S. \& Joo, Y.M. (2015). The effects of exhibition service quality on exhibitor satisfaction and behavioral intentions. Journal of Hospitality Marketing \& Management, 24 (7), 683-707.

Lin, C., \& Lin, C. (2013). Exhibitor perspectives of exhibition service quality. Journal of

Convention and Event Tourism, 14(4), 293-308.

Malholtra, N. K. (2004). Marketing Research: An Applied Orientation (4 ${ }^{\text {th }}$ Ed.). New Jersey:

Pearson Education, Inc.

Oliver, R. L. (1980). A cognitive model of the antecedents and consequences of satisfaction decisions. Journal of Marketing Research, 16, 39-54.

Oliver, R. L. (1997). Satisfaction: A behavioral perspective on the consumer. New York: McGraw-Hill. Parasuraman, A., Zeithaml, V. A., \& Berry, L. L. (1988). Servqual: A multiple-item scale for measuring consumer perception. Journal of Retailing, 64(1), 12.

PEMANDU, (2010). Economic Transformation Programme, 2010. A roadmap for Malaysia.

Putrajaya: Performance Management and Delivery Unit (PEMANDU). Retrieved from www.tp.pemandu.gov.my.

Rainbolt, G., Benfield, J., \& Loomis, R. (2012). Visitor self-report behavior mapping as a tool for recording exhibition circulation. Visitor Studies, 15(2), 203.

Rittichainuwat, B., \& Mair, J. (2012). Visitor attendance motivations at consumer travel exhibitions. Tourism Management, 33, 1236-1244.

Shemwell, D.J., Yavas, U., \& Bilgin, Z. (1998). Customer-service provider relationships: an empirical test of a model of service quality, satisfaction and relationship-oriented outcomes. International Journal of Service Industry Management, 9(2), 155-168. 
Smith, T.M., Hama, K., \& Smith, P.M. (2003). The effect of successful tradeshow attendance on future show interest: exploring Japanese attendees' perspectives of domestic and offshore international events. Journal of Business \& Industrial $\quad$ Marketing, 18, 403-418.

Sureshchandar, G.S., Rajendran, C., \& Anantharaman, R.N. (2002). The relationship between service quality and customer satisfaction - a factor specific approach. Journal of Services Marketing, 16(4), 363-379.

Wan, P., \& Siu, N. (2012). The impact of the servicescape on the desire to stay in convention and exhibition centers: The case of Macao. International Journal of Hospitality Management, 31(1), 236-246.

Whitfield, J., \& Webber, D. (2011). Which exhibition attributes create repeat visitation? International Journal of Hospitality Management, 30, 439-447.

Zhang, Y., Lee, D., Judge, L.W., \& Johnson, J.E. (2014). The relationship among service quality, satisfaction, and future attendance intention: the case of Shanghai ATP Master 1000. International Journal of Sports Science, 4, 50-59. 